\title{
Quality Concerns and Best Practices in Open and Distance Learning
}

\author{
Dr. Vikas Sharma, Dr. Anuradha Goswami
}

\begin{abstract}
The quality of education would play a crucial role in balancing the socio economic framework of the country like India which is in the transactional phase of knowledge based society. Education should be such that it builds an inner strength of our people. It should bring our ancient heritage to the new generation, it makes available our aesthetic treasures to the young generation. Education permeates every aspect of life. It must be such that it brings the best out of our past, takes the best of the present. As classroom based teaching continues to be the main form of education which require higher demands on physical infrastructure and human resources, our country is not able to impart education to every single child. The aim of making education accessible to all can be accomplished if various modes such as formal and non-formal are effectively deployed to fulfill the existing educational needs of the prospective learners. Thus the needs was felt to establish distance educational system to provide educational to those who for one reason or the other cannot avail the opportunities of formal education.
\end{abstract}

\section{Introduction}

Educational institutions are the treasures of knowledge. These are the agents of social change and transformation. Higher education which was primarily considered to be affordable for a limited section in the society, today, by virtue of 'open education', this participation can be widened by making it available at free or low cost of the remaining majority. The movement of open education has the potential to address the barriers of higher education and introduce several alternatives for the underprivileged who aspire to complete higher education.

Distance education has really opened new window of opportunities for those who desire for further studies. In a way it has helped numerous professional, dropouts, housewives, etc to accomplished their unfinished dreams, The whole purpose of providing distance education is to provide cost-effective, quality education to large sections of our populations including those living in remote and far flung areas. Distance learning caters to the educational needs of the target groups, through the open of learning and provide facility to study according to their own pace and convenience to the distance learners. The distance education system provides opportunities not only to the young students but also to those from the older age groups. The main reason for increasing interest in distance education lies in the need for continuing education in today's competitive world.

\section{Courses of Study}

Various courses available in different distance teaching institutes range from conventional general undergraduate programme to technical and vocational courses. Most of the institutes including the first Open University, started with the general undergraduate programme. The growth rate of enrollment in distance education is higher than in the formal system. Need of the hour is to introduce skill based programme through ODL system. The distance learning institute needs to introduce skill based programme, and make use of information and communication technology to make possible pathways for learners with an emphases on relevant hands on experience and allow learners to enter job market and also pursue higher education. Higher education including open and distance learning is an instrument of transformation.

\section{Open and distance learning: A highly potential alternative}

Open and distance learning is also a highly potential system of expanding education to the people when conventional classrooms have failed to keep up with the population of the country that has been growing at a geometrical progression. The annual growth rate of enrollment in distance education during the last 10 years has been much higher than that in the formal education system. The Government of India has taken up quite a few ambitious and expensive ICT projects for delivery of services to the masses at the grassroots level across the length and breadth of the country taking advantage of the recent advances in this field. This can be utilized towards a better literacy drive in future.

ODL learners are not a homogeneous community. They may include younger ones, middle aged and older ones. They might belong to literate, semi-literate, skilled, semi-skilled and unskilled categories. They may 
also be employed, physically challenged or differently-abled. The learner groups will choose the relevant programme of study to continue their studies. The main components of these to be supplied to the learners include self-instructional material, audio video discs, reference books through libraries. At times learners from research category are attracted towards DE and try to use its tools and methodologies to complete their research programme.

\section{Promotion and Best Practices in Distance Education}

Higher education including open and distance leaning is an instrument of transformation. We have to keep pace with change. It is gratifying to note that during the twelth plan period, we have focused on expansion, equity, excellence, governance, funding and monitoring. This transformation cannot come about without high quality of the system and what the system offers. Quality assurance must cover areas such as curriculum design, content and delivery organization, teaching, learning and assessment etc. The academic curriculum has to be update regularly. The assessment system has to be made more reliable and objective.

In the area of innovation and creativity the distance education system need to introduce proper communication with learners through SMS, Ticket System, Toll free number, E-mail, video lectures, video recordings, and short term courses by various department. Some of distance learning open universities have even set up study center to provide students support service. Maintaining their identity, quantity, reliability and to reach the common masses, university has to do maximum publicity 'with regard to the university programme and events through electronic and print media i.e. Newspaper, Reports, Seminar / Conferences organized by the university, counseling of the learner, mobile ban etc.

In this era of information and technology, learner needs to be able to learn to use technology as a tool in itself. Countries world-over are trying to capitilise on the enormous beneficial development of information and communication technology for taking the government services to the people as much as possible. In other words delivering services at the doorsteps of people. This is because ICT includes a range of technologies and facilitates communication, processing and transmission of information by electronic means. It helps the rural poor in their daily life especially when it comes to practical matters like telecommunication and access to information. They also increase empowerment and give voice to the rural community. open and distance learning has been improvised upon by integrating various other methods such as:-

- Virtual Education

- Alternative Education

- E Learning

\section{Virtual Education}

Virtual education is a term describing online education using the internet. A virtual programme is a study programme in which all courses or at least significant portion of the courses are virtual courses in that they are not taught in a classroom face to face but through some substitute mode that can be associated with classroom teaching.

In the international era, virtual education grows everyday offering programmes in basic and secondary education, as well as under graduate and post-graduate degrees. Many universities, sensitive about the distance problem of many of their candidates, and of the schedule difficulties in others, have began to implement virtual programmes with the purpose of reaching those students that cannot assist to their campus.

\section{E Learning}

The E-learning can provide and opportunity to access literature/information/ knowledge related to the curricular areas with fair degree of mobility. Electronic learning or E-learning is a type of education where the medium of instruction is computer technology. It involves planned teaching or learning experiences that use a wide spectrum of technologies, mainly the internet to reach learner at a distance. E-learning is dominating globally, it is one of the important and major technological developments that lead to the developments in area of learning or education.

\section{Alternative Education}

The twentieth century is experiencing increased interest in the distance education as a means of equalising educational opportunities providing education to a scattered population over vast distance, offering education to deprived and disadvantaged sections of the society. Alternative education, also known as nontraditional education or educational alternatives, includes a number of approaches to teaching and learning other than main stream or traditional education. While some educational alternatives have strong political, scholarly or philosophical orientations, others are more informal association of teachers and students dissatisfied with some or the other aspects of traditional or main stream education. Educational alternatives include charter schools, alternative schools, independent schools and home based learning. 


\section{Plan of Action}

The quality filters from top to bottom. Therefore, a monitoring committee reformed by IDE with someone as its coordinator. Following maybe a plan of action to bridge the gap between perception and expectation for various activities as well as manpower.

1. Manpower deployed providing human support to students be oriented about their role and responsibilities with distance learners. A staff development programme maybe chalked out for them using distance education mode.

2. Students orientation must cover their role and responsibilities in distance education system. For this purpose "student Hand-book" maybe redrafted and few topics be added. These maybe like - how to study in a distance education scenario; skills for writing assignments; generating motivation and interest for study. Optimum use of various media like email, fax, phone, cell, etc. to contact teachers.

3. To design programmes to meet new quality standards.

4. To compete in the global market in terms of quality as well as cost effectiveness.

5. Necessary financial requirements (Budget) be prepared and submitted to authorities for allocation.

6. Course maintenance of the learning material may be done by seeking the help of experts working in the universities or outside universities. It will make the learning material more enriched with latest information.

7. The programme coordinators in IDE must organize a monthly meeting with concerned teachers to know their academic and administrative programmes and bring it before IDE staff meeting for an appropriate solution. It would help each other to exchange views and accept best practices among them.

\section{Conclusions}

Distance education has really opened a new window of opportunities for those who desire for further studies. A large number of students can study at their own rate, pace and time. The survival, growth and prosperity of an institution of ODL depends not only on widening the access to higher education but also on enriching the curricula and strengthening the governance of the institutions. The system of distance education is a ray of hope for mass education among people of India. It would attract a large number of students for different programmes in future, and may fulfill the country's requirements of competent manpower. This is possible only when the system imparts a quality education which is not inferior to that which is offered by conventional system.

\section{References}

[1]. Prakash P. \& P. Krishna Rao (2012), Issues in Open and Distance Education, University News, Vol. 50, No. 35 , Aug. 27 -Sept. 02.

[2]. Bara and Ratul Chandra Nath (2013), ICT in Open and Distance Learning, University News, Vol 51, No. 23, June 10-16.

[3]. Vijyalaxmi P., (2013), ODL for overcoming Global knowledge tensions in the new Millennium, University News, Vol 51, No. 14, april 8-14.

[4]. Kurhade M.S. (2009), Open \& Distance Learning for a Brighter tomarrow, University News, Vol. 47, No. 20 , May 18-24.

[5]. Goswami, Anuradha (2008), Factorization of Personality Dispositions of Women Distant Learners of J\&K State.

[6]. Jayaprakash, Appani (2014), Quality Assurance In Library Services for Distance Learners in ODL System Challenges and Development, IDEA Conference -2014 in collaboration with Directorate of Distance Education, University of Jammu, 12 - 14 March 2014. 